\title{
Effects of Chemical Composition and Oxidation Temperature on the Adhesion of Scale in Plain Carbon Steels
}

\author{
Taro KIZU, Yasunobu NAGATAKI, Toru INAZUMI and Yoshihiro HOSOYA \\ Materials and Processing Research Center, NKK Corporation, Kokan-cho, Fukuyama 721-8510 Japan.
}

(Received on May 10, 2001; accepted in final form on September 5, 2001)

\begin{abstract}
Effects of chemical composition and oxidation temperature on blistering and delaminating of scales formed on steels were investigated. The scale blistering occurred for steels with $\mathrm{P}$ content above 0.005 mass \%. Low carbon steels with 0.01 mass $\%$ Si- 0.2 mass $\% \mathrm{Mn}-0.01$ mass \% P showed pronounced blistering at $1223 \mathrm{~K}$. The temperature at which the time to blistering is the shortest, the prominent temperature, decreased with increasing $\mathrm{Mn}$ and $\mathrm{P}$ contents and deceasing Si content in steels. There was no effect of C, S and sol. Al contents on the such specific temperature. The blistering was promoted by increasing $\mathrm{C}, \mathrm{Mn}$ and $\mathrm{P}$ contents and suppressed by increasing $\mathrm{S}$ content at any temperature. The blistering was suppressed at $1223 \mathrm{~K}$ by increasing Si content but promoted at $1323 \mathrm{~K}$. Sol. Al showed no effect on the acceleration of blistering. The blistering would be correlated to scale texture and segregation of minor elements at the interface between scale and substrate. $\{111\}$ and $\{110\}$ oriented crystals in $\{100\}$ matrix of FeO, that were preferable with increased Si, Mn and P contents, decreased S content and oxidation temperature, accelerated the blistering. The segregated $\mathrm{P}$ promoted by increasing $\mathrm{P}$ content and decreasing oxidation temperature accelerated the blistering, whereas the segregated Si promoted by increasing Si content and decreasing oxidation temperature suppressed it.
\end{abstract}

KEY WORDS: low carbon steel; scale; oxidation; blistering; segregation; texture.

\section{Introduction}

Recently, demand for surface quality of steel sheet has become more intense. One of the major defects which deteriorate surface quality is rolled-in-scale during hot-rolling, particularly within tandem finishing-mill stands. In recent years, high-speed steel rolls have been developed ${ }^{1-3)}$ to prolong the life of hot-rolling work-rolls and they promote the rolled-in-scale defects by increasing the friction coefficient. $^{4,5)}$

The occurrence of rolled-in-scale defects strongly depends on adhesion of scales formed on steel surface by high temperature oxidation, and scale blistering during hotrolling seriously deteriorates surface quality by embedding fragmented scales into the steel substrate. ${ }^{6}$ Matsuno reported that the blistering occurred at a specific temperature range $^{7)}$ and the effect of impurity level of steels on the blistering was investigated by Tylecote ${ }^{8)}$ and Modin. ${ }^{9}{ }^{9}$ However, there are few systematic studies for combined effects of temperature and chemical composition of steels on the blistering.

The scale blistering can be estimated by the balance between adhesive and delaminating forces at the interface between scale and substrate. It was suggested that CO gas at the interface reduced the adhesive force, ${ }^{10)}$ and segregation of specific elements at the interface may affect the adhesive force. Compressive stress within scale has been suggested to affect the delaminating force. ${ }^{11,12)}$ For example, Pilling and Bedworth have suggested that the growth of oxide layer generates compressive stress when the volume per metal ion in the oxide is larger than that in the metal. ${ }^{13)}$ However, this idea is not applicable for the oxidation of steels because steel is oxidized by outward diffusion of $\mathrm{Fe}^{2+}$ ion through the scale ${ }^{14)}$ and there is no satisfactory explanation of the stresses.

The purpose of this study is to clarify quantitative effects of the chemical composition and temperature on the scale blistering and to discuss dominant factors of scale adhesion from the viewpoints of crystalline texture of scale and segregation of elements.

\section{Experimental Procedure}

The steels used in this investigation were vacuum melted and cast into $50 \mathrm{~kg}$ ingots. Chemical compositions are shown in Table 1. Carbon content was varied from 0.0022 to 0.138 mass $\%$. For the 0.04 mass $\%$ C steels, $\mathrm{Si}, \mathrm{Mn}, \mathrm{P}, \mathrm{S}$ and sol. Al contents were varied. Oxidation test specimens, $1.5 \times 40 \times 50 \mathrm{~mm}^{3}$, were cut from hot-rolled bands and the surface was finished with $5 \mu \mathrm{m}-\mathrm{Al}_{2} \mathrm{O}_{3}$. The specimens were heated in an infrared furnace with a $100^{\Phi} \mathrm{mm}^{2} \times 600^{1}$

Table 1. Chemical compositions of steels used (mass\%).

\begin{tabular}{|c|c|c|c|c|c|c|c|}
\hline & $\mathrm{C}$ & $\mathrm{Si}$ & $\mathrm{Mn}$ & $\mathrm{P}$ & $\mathrm{S}$ & $\mathrm{sol}$ Al & $\mathrm{N}$ \\
\hline Base & 0.04 & $0.01-0.02$ & 0.2 & 0.01 & 0.01 & 0.02 & 0.002 \\
\hline Series & $0.0022-0.138$ & $0.01-0.05$ & $0.24-1.43$ & $0.002-0.05$ & $0.004-0.05$ & $0.019-0.091$ & - \\
\hline
\end{tabular}


mm specimen chamber made of transparent quartz glass. Specimens were held isothermally at temperatures of 1223$1323 \mathrm{~K}$ for $30 \mathrm{sec}$ to complete austenite transformation in a $\mathrm{N}_{2}$ atmosphere. Subsequently, dry air was introduced to the chamber at a pressure of $4.9 \times 10^{3} \mathrm{hPa}$ and volume of $100 \mathrm{l}$ per min at temperatures of $1173-1323 \mathrm{~K}$. Oxidation was performed for 3-100 sec with holding air pressure of $1013-1317 \mathrm{hPa}$. After oxidation, specimens were gradually cooled to room temperature at a cooling rate of $1 \mathrm{~K}$ per sec in a $\mathrm{N}_{2}$ atmosphere to minimize thermal strain within the scale layer.

The weight of the specimens was measured before and after oxidation to evaluate the scale growth. Scale delaminating was observed by appearance of the specimen surface after cooling. Cross sections of oxidized specimens were analyzed by Electron Probe Microanalysis (EPMA) in order to investigate the segregation of elements quantitatively. The distribution of elements in the scale and the substrate was determined by Secondary Ion Mass Spectrometry (SIMS). Sputter depth profiles by SIMS were recorded from $60^{\Phi} \mu \mathrm{m}^{2}$ areas of the scale surface, using $8 \mathrm{keV}$ $\mathrm{O}_{2}^{+}$primary ions rastered over $250 \times 250 \mu \mathrm{m}^{2}$. X-ray Diffractometry (XRD) was used in order to identify chemical constitution and crystalline texture of the scales. The target, voltage and current used were $\mathrm{Cu}, 45 \mathrm{kV}$ and 200 $\mathrm{mA}$, respectively. Residual stress within the scale layer was measured by iso-inclination method of XRD. ${ }^{15)}$ The target, voltage and current used were $\mathrm{Cr}, 40 \mathrm{kV}$ and $250 \mathrm{~mA}$, respectively. Cross sections of the scales were observed by Scanning Electron Microscope (SEM) after etching. The etching solution was made of $5 \%$ thioglycollic acid, $5 \%$ phthalate dipotassium aqueous solution, 5\% ammonium citrate aqueous solution and $5 \%$ citric acid mixed at a ratio of $10: 5: 2: 3 .^{16)}$

\section{Results}

\subsection{Effects of Oxidation Temperature and Chemical Composition on Scale Blistering}

Surface appearances of tested specimens are shown in Fig. 1 for 0.05 mass\% P steels oxidized at 1 173, 1223 and $1273 \mathrm{~K}$ for $10 \mathrm{sec}$. The scale formed uniformly on the substrate oxidized at $1273 \mathrm{~K}$ and small blisters shown by arrows appeared at $1173 \mathrm{~K}$. For the specimen oxidized at $1223 \mathrm{~K}$, small blisters coalesced and the scale was separated from the substrate. Figure 2 shows the effect of oxidation time and temperature on the scale blistering. The time to blistering was the shortest at $1223 \mathrm{~K}$. This tendency is similar to the results of Matsuno. ${ }^{7}$ The blistering was suppressed at 1273 and $1173 \mathrm{~K}$, and this suppression tendency was more pronounced at $1273 \mathrm{~K}$. As is generally known, the scale growth rate is represented as a function of time and temperature. With 0.05 mass $\% \mathrm{P}$ steel, the oxidation weight gain, $X\left(\mathrm{mg} \cdot \mathrm{cm}^{-2}\right)$, was measured and is written as follows,

$$
X=1.2 \times 10^{5} \exp (-15000 / T) t^{1 / 2}
$$

here, $T(\mathrm{~K})$ is oxidation temperature and $t(\mathrm{~s})$ is oxidation time. At 1173 and $1223 \mathrm{~K}$, the scale blistering occurred when $X$ reached about $1-1.5 \mathrm{mg} \cdot \mathrm{cm}^{-2}$. In this temperature range, the blistering onset time decreased with increasing

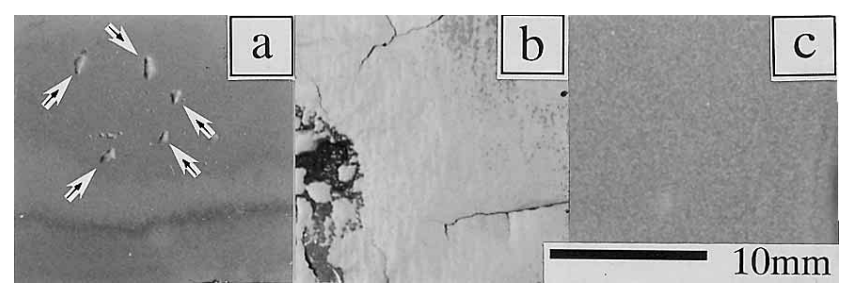

Fig. 1. Appearance of cooled specimens after oxidation for 0.05 mass $\%$ P steels. (a) Oxidized at $1173 \mathrm{~K}$ for $10 \mathrm{~s}$, (b) oxidized at $1223 \mathrm{~K}$ for $10 \mathrm{~s}$, (c) oxidized at $1273 \mathrm{~K}$ for $10 \mathrm{~s}$.

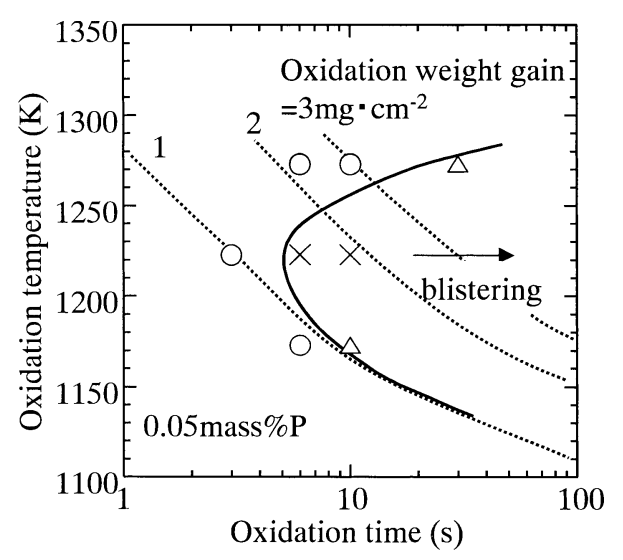

Fig. 2. Effect of oxidation time and temperature on the blistering and oxidation weight gain for 0.05 mass $\% \mathrm{P}$ steels. $\bigcirc$; uniform scale, $\triangle$; small blisters appeared under the scale, $\times$; complete blistering of scale.

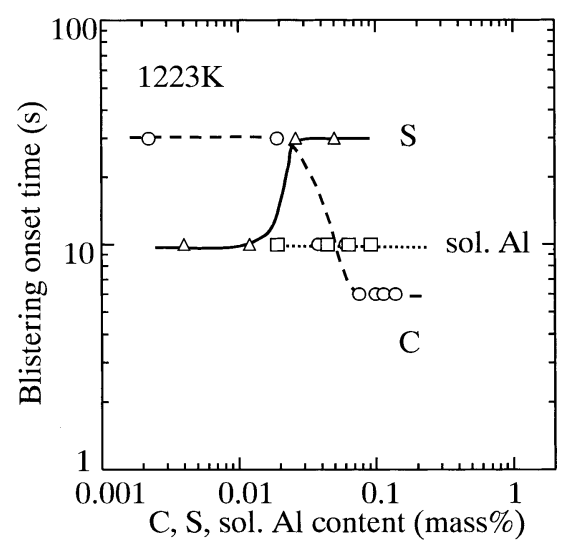

Fig. 3. Effect of $\mathrm{C}, \mathrm{S}$ and sol. Al contents on the onset time of blistering at $1223 \mathrm{~K}$.

temperature due to an increase in the scale growth rate. At temperatures higher than $1223 \mathrm{~K}$, however, the blistering onset time increased with increasing temperature in spite of an increase in the scale growth rate. Therefore, other dominant factors besides the kinetics of scale growth should be considered. This $\mathrm{C}$-shaped curve relationship between the blistering onset time and oxidation temperature was observed for other steels in this study. The temperature at which the time to blistering is the shortest, $T_{\mathrm{s}}$, was affected by the $\mathrm{Si}, \mathrm{Mn}$ and $\mathrm{P}$ contents, but there was no effect of $\mathrm{C}$, $\mathrm{S}$ and sol. Al contents on $T_{\mathrm{s}}$.

Figure 3 shows the effects of $\mathrm{C}, \mathrm{S}$ and sol. Al contents on the blistering onset time at $1223 \mathrm{~K}$ where the blistering was the most accelerated. An increase in $\mathrm{C}$ content accelerated the blistering and an increase in $\mathrm{S}$ content suppressed 


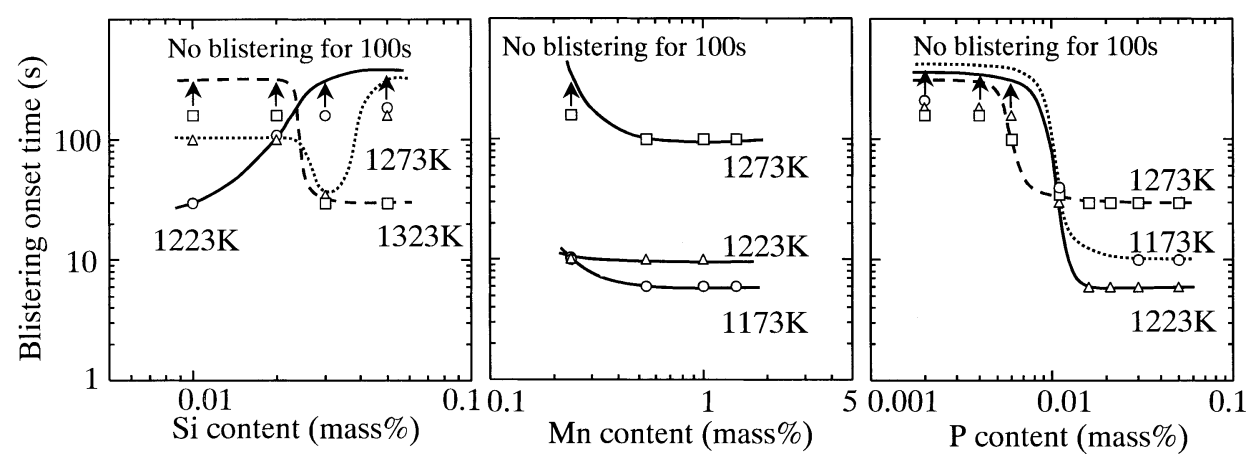

Fig. 4. Effect of $\mathrm{Si}, \mathrm{Mn}$ and $\mathrm{P}$ contents and oxidation temperature on the blistering onset time.

it. Sol. Al showed no effect on the blistering.

Figure 4 shows the effect of $\mathrm{Si}, \mathrm{Mn}$ and $\mathrm{P}$ contents on the blistering onset time at temperatures of 1173-1323 K. With Si steel series, the blistering was suppressed at 1223 $\mathrm{K}$ and accelerated at $1323 \mathrm{~K}$ with increasing Si content. At $1273 \mathrm{~K}$, the blistering onset time showed a minimum at 0.03 mass $\%$. Consequently, $T_{\mathrm{s}}$ rose from 1223 to $1323 \mathrm{~K}$ with increasing Si content. With Mn steel series, Mn promoted the blistering at 1173 and $1273 \mathrm{~K}$. The blistering onset time was the shortest at $1173 \mathrm{~K}$ for steels with more than 0.5 mass $\%$ Mn. With P steel series, the blistering took place for $\mathrm{P}$ content higher than 0.005 mass $\%$. P promoted the blistering at all temperatures, and $T_{\mathrm{s}}$ fell from 1273 to $1223 \mathrm{~K}$ with increasing P content.

As described above, $\mathrm{Si}, \mathrm{Mn}$ and $\mathrm{P}$ affect the blistering. Particularly, reduction of $\mathrm{P}$ content to less than 0.005 mass \% suppressed the blistering even for $100 \mathrm{sec}$ oxidation at any temperature, and the addition of $\mathrm{Si}$ at higher than 0.02 mass $\%$ suppressed the blistering completely at 1223 $\mathrm{K}$. With 0.01 mass $\% \mathrm{Si}-0.01$ mass $\% \mathrm{P}$ steel, reduction of $\mathrm{Mn}$ content to less than 0.3 mass $\%$ suppressed the blistering completely at $1273 \mathrm{~K}$.

\subsection{Segregation of $\mathrm{Si}$ and $\mathrm{P}$ at the Interface between Scale and Substrate}

An EPMA analysis showed that $\mathrm{Si}$ and $\mathrm{P}$ segregated at the interface between scale and substrate and that $\mathrm{Mn}$ and $\mathrm{S}$ distributed homogeneously within the scale. Figure 5 shows the effect of oxidation temperature on Si concentration of 0.5 mass $\%$ Si steel and on P concentration of 0.05 mass \% P steel at the interface. Here, Si and P concentrations were measured with the steels oxidized for 10 and 3 sec, respectively. Both $\mathrm{Si}$ and $\mathrm{P}$ concentrations decreased with increasing oxidation temperature.

Figure 6 shows the relationship between $\mathrm{Si}$ and $\mathrm{P}$ contents of specimens and their concentrations at the interface between scale and substrate. Si and P concentrations at the interface were about 5 times higher than in the matrix and increased as $\mathrm{P}$ and $\mathrm{Si}$ contents increased.

To examine the distribution of $\mathrm{Si}$ and $\mathrm{P}$ at the interface between scale and substrate, ${ }^{30} \mathrm{Si},{ }^{31} \mathrm{P}$ and ${ }^{18} \mathrm{O}$ profiles from the scale surface were analyzed by SIMS. Figure 7 shows the relationship between sputtering time and secondary ion counts of $0.05 \mathrm{mass} \% \mathrm{Si}-0.01 \mathrm{mass} \% \mathrm{P}$ steel and 0.05 mass $\% \mathrm{P}-0.02 \mathrm{mass} \% \mathrm{Si}$ steel. Since secondary ion counts of mass number 28, 29 and 30 of Si isotope showed the similar profiles, $\mathrm{Si}$ is considered to exist. ${ }^{17)}$ Secondary

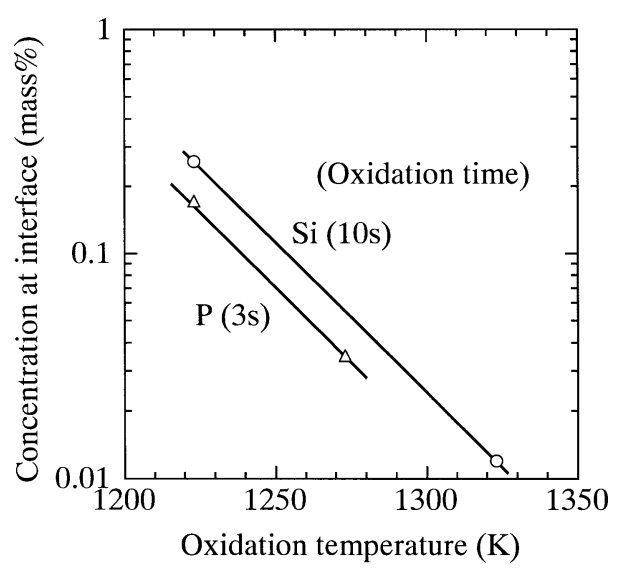

Fig. 5. Effect of oxidation temperature on Si and P concentrations at the interface between scale and substrate with steels oxidized for $10 \mathrm{~s}(\mathrm{Si} ; \mathrm{O}, 0.05 \mathrm{mass} \% \mathrm{Si}$ steel) and $3 \mathrm{~s}(\mathrm{P} ; \triangle, 0.05$ mass\% P steel).

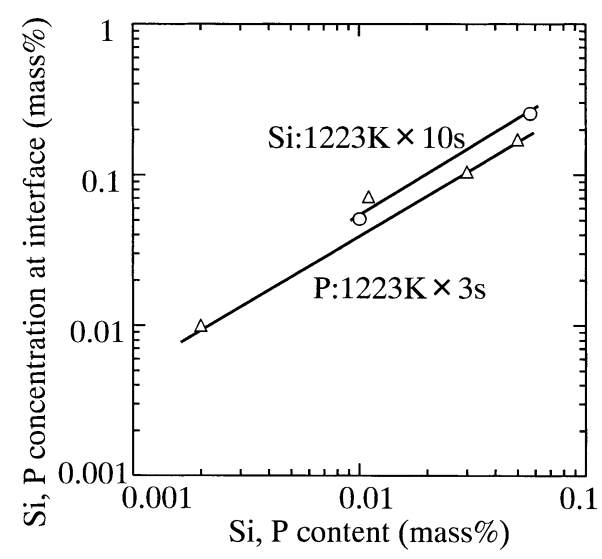

Fig. 6. Effects of $\mathrm{Si}$ and $\mathrm{P}$ contents of specimens on $\mathrm{Si}$ and $\mathrm{P}$ concentrations at the interface between scale and substrate with steels oxidized at $1223 \mathrm{~K}$ for $10 \mathrm{~s}(\mathrm{Si} ; \mathrm{O})$ and $3 \mathrm{~s}(\mathrm{P} ; \triangle)$.

ion counts of mass number 31 did not decrease so much when the bias voltage was applied to the specimen to eliminate the effect of molecule ion, and that increased as P content increased, so that $\mathrm{P}$ is also considered to exist. ${ }^{17)}$ In Fig. 7, $\mathrm{Si}, \mathrm{P}$ and $\mathrm{O}$ depth profiles were represented by secondary ion counts of mass number 30, 31 and 18, respectively. Since the shapes of Si and P counts were similar, both elements are considered to segregate at the same place in the interface between scale and substrate. Both $\mathrm{Si}$ and $\mathrm{P}$ counts increased just before $\mathrm{O}$ counts began to decrease with in- 

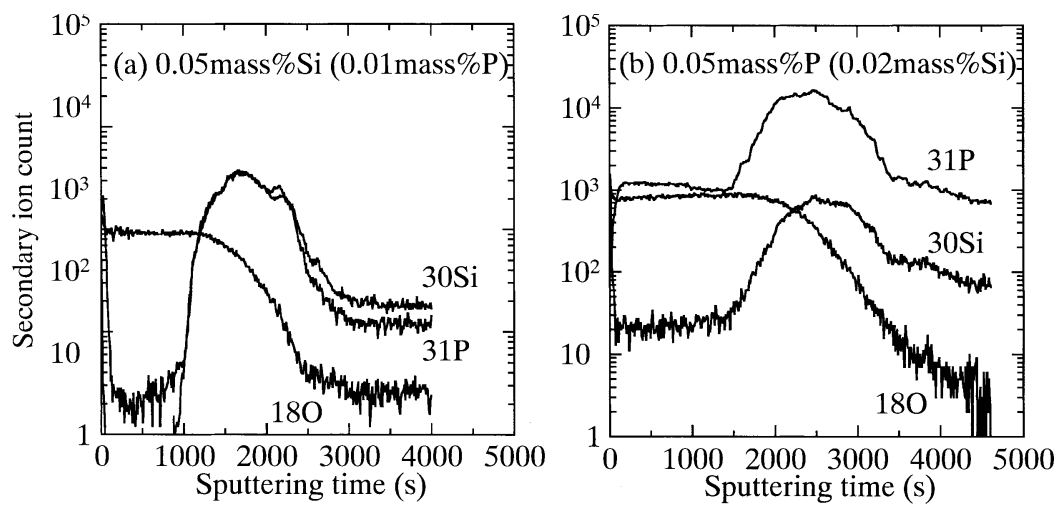

Fig. 7. SIMS composition-depth profiles across the scale and substrate with steels oxidized at $1223 \mathrm{~K}$ for $3 \mathrm{~s}$. (a) 0.05 mass\% Si (0.01 mass\% P) steel, (b) 0.05 mass\% P (0.02 mass\% Si) steel.
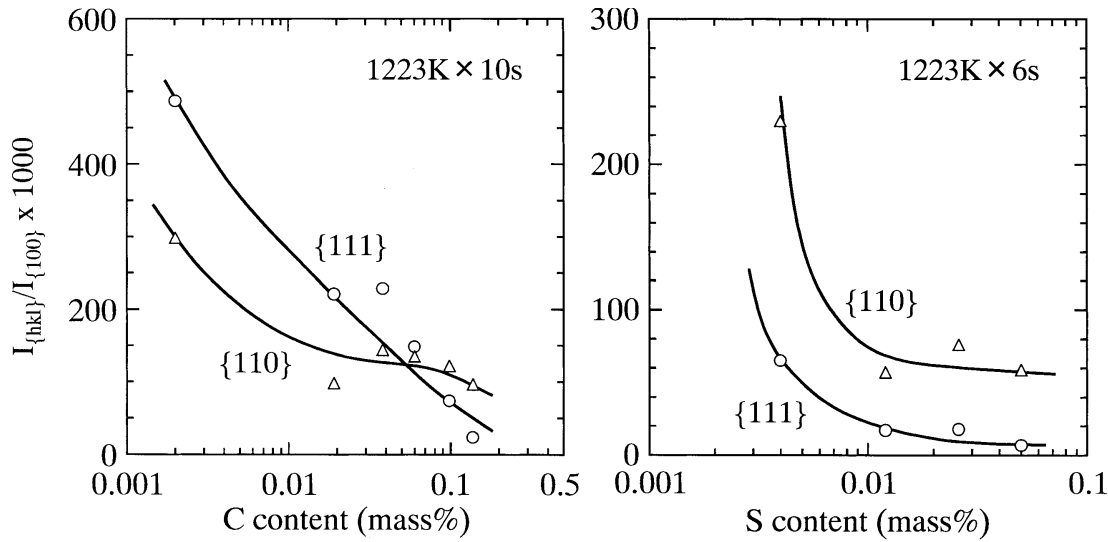

Fig. 8. Effect of $C$ and $S$ contents on intensity ratios of $X R D$ peak heights. $O ;\{111\}, \triangle,\{110\}$. $C$ steel series; $1223 \mathrm{~K} \times$ $10 \mathrm{~s}$, S steel series; $1223 \mathrm{~K} \times 6 \mathrm{~s}$.
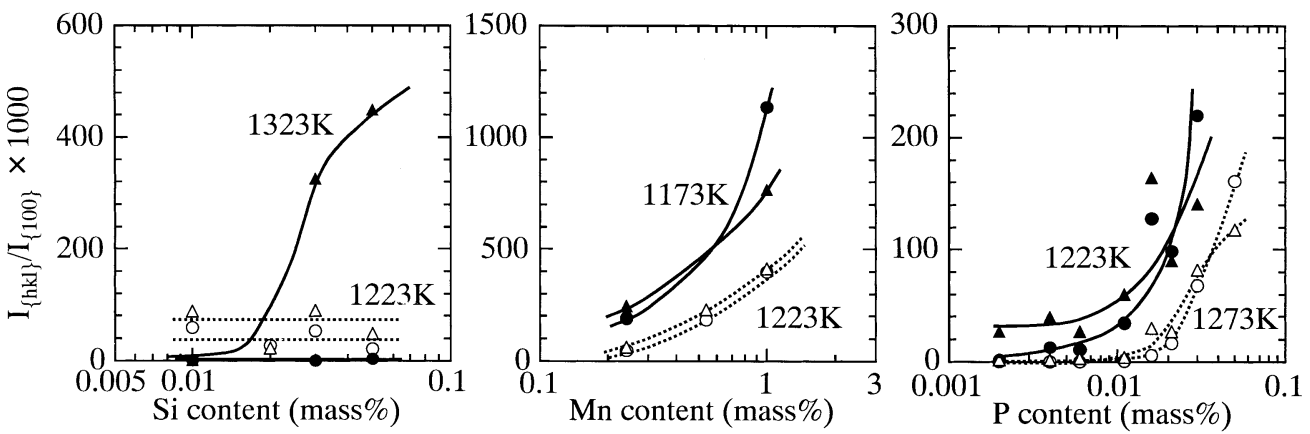

Fig. 9. Effect of $\mathrm{Si}, \mathrm{Mn}, \mathrm{P}$ contents and oxidation temperature on intensity ratios of XRD peak heights. $\bigcirc \mathbf{O}\{111\}, \triangle \boldsymbol{\Lambda}$ $\{110\}$. Si steel series; $1223 \mathrm{~K} \times 10 \mathrm{~s}$ (solid) and $1323 \mathrm{~K} \times 10 \mathrm{~s}$ (open), Mn steel series; $1173 \mathrm{~K} \times 3 \mathrm{~s}$ (solid) and $1223 \mathrm{~K} \times 6 \mathrm{~s}$ (open), P steel series; $1223 \mathrm{~K} \times 3 \mathrm{~s}$ (solid) and $1273 \mathrm{~K} \times 10 \mathrm{~s}$ (open).

creasing sputtering time and segregated Si and $\mathrm{P}$ are considered to exist on the scale side of the interface.

\subsection{Texture of Scale}

An XRD analysis showed that the scales formed on all specimens were mainly composed of Wuestite $(\mathrm{FeO})$. The strongest fiber texture of $\mathrm{FeO}$ parallel to the surface was $\{100\}$ component as reported previously. ${ }^{18,19)}$ Intensities of other crystalline orientations of $\mathrm{FeO},\{111\}$ and $\{110\}$ components, changed with composition of steels and oxidation temperature. Figure 8 shows the effect of $\mathrm{C}$ and $\mathrm{S}$ contents on the ratios of $\{111\}$ and $\{110\}$ peak heights with the value of 1000 set at $\{100\}$ peak height, $I_{\mathrm{r}\{111\}}$ and
$I_{\mathrm{r}\{110\}}$, for the specimens oxidized at $1223 \mathrm{~K} . I_{\mathrm{r}\{111\}}$ and $I_{\mathrm{r}\{110\}}$ decreased as $\mathrm{C}$ and $\mathrm{S}$ contents increased. Figure 9 shows the effect of $\mathrm{Si}, \mathrm{Mn}$ and $\mathrm{P}$ contents on $I_{\mathrm{r}\{111\}}$ and $I_{\mathrm{r}\{110\}}$ at various temperatures. Both $I_{\mathrm{r}\{111\}}$ and $I_{\mathrm{r}\{110\}}$ did not depend on Si content at $1223 \mathrm{~K}$, but $I_{\mathrm{r}\{110\}}$ increased as Si content increased at $1323 \mathrm{~K} . I_{\mathrm{r}\{111\}}$ and $I_{\mathrm{r}\{110\}}$ increased with increasing $\mathrm{Mn}$ and $\mathrm{P}$ contents and with decreasing oxidation temperature, and the latter was pronounced for high Mn content steels.

\section{Discussion}

In this study, the effect of oxidation time and temperature 
on the scale blistering was assessed by a C-shaped curve (Fig. 2), and the blistering was affected by chemical composition of steels. The blistering is accelerated by an increase in the scale growth rate as oxidation temperature rises up to $1223 \mathrm{~K}$. However, the restraint of the blistering in the higher temperature range and the effect of chemical composition cannot be rationalized from the scale growth rate. In this study, segregation of $\mathrm{Si}$ and $\mathrm{P}$ at the interface and the scale texture were shown to be affected by oxidation temperature and chemical composition. Based on these results, it is supposed that the scale texture and segregation of elements are more effective on the blistering than the scale growth.

\subsection{Effect of Scale Texture on Blistering}

Generally, growth rate of scale is assumed to be different with crystal plane, and it is expected that inclusion of $\{111\}$ or $\{110\}$ oriented crystal in $\{100\}$ matrix grains may lead an increase in stress in the scale.

Next, we estimate the volume fraction of $\{111\}$ and $\{110\}$ oriented crystals of $\mathrm{FeO}$ from the intensity ratios of XRD peaks. The relative integrated intensity, $I$, can be calculated approximately as follows, ${ }^{20)}$

$$
I=|F|^{2} p\left(\left(1+\cos ^{2} 2 \theta\right) /\left(\sin ^{2} \theta \cos \theta\right)\right) .
$$

here, $F$ is structure factor, $p$ is multiplicity factor and $\theta$ is Bragg angle. As $\mathrm{FeO}$ have $\mathrm{NaCl}$ type cubic structure, $F$ can be expressed as follows,

$$
\begin{array}{ll}
F=4\left(f_{\mathrm{Fe}}+f_{\mathrm{O}}\right) & (h+k+l=\text { even number }) \\
F=4\left(f_{\mathrm{Fe}}-f_{\mathrm{O}}\right) & (h+k+l=\text { odd number }) .
\end{array}
$$

here, $f$ is atomic scattering factor and $(h k l)$ are Miller indices. Table 2 shows the result of calculation using wavelength of $\mathrm{CuK} \alpha_{1}, \lambda$, is $1.5405 \AA$. From the relative integrated intensities of Table 2, volume fraction of (111) and (220), $V$, can be calculated as follows.

$$
\begin{aligned}
& V_{(111)}=I_{(111)} / 0.599 /\left(I_{(111)} / 0.599+I_{(200)}+I_{(220)} / 0.812\right) \ldots \\
& V_{(220)}=I_{(220)} / 0.812 /\left(I_{(111)} / 0.599+I_{(200)}+I_{(220)} / 0.812\right) \ldots(6)
\end{aligned}
$$

Figure 10 shows the relationship between the blistering onset time and the sum of volume fraction of $\{111\}$ and $\{110\}$ oriented crystals in $\mathrm{FeO}, V_{\{111\}}+V_{\{110\}}$. It is clear that inclusion of $\{111\}$ and $\{110\}$ oriented crystals in $\{100\}$ matrix of $\mathrm{FeO}$ decreased the blistering onset time irrespective of the impurities and oxidation temperatures. As shown in Fig. 5, concentrations of $\mathrm{Si}$ and $\mathrm{P}$ segregated at the interface between scale and substrate are high at $1223 \mathrm{~K}$, and results of $\mathrm{Si}$ and $\mathrm{P}$ series at $1223 \mathrm{~K}$ were excluded from this figure. Results of $\mathrm{C}$ series were also excluded, because $\mathrm{C}$ may generate $\mathrm{CO}$ gas at the interface and accelerate the blistering. Effects of segregation and $\mathrm{CO}$ gas evolution will be discussed at Sec. 4.3. In summary, there is marked correlation between the growth texture in $\mathrm{FeO}$ and the acceleration of the blistering.

\subsection{Effect of Scale Texture on Stress Generation with- in the Scale}

It is anticipated that an increase in $V_{\{111\}}+V_{\{110\}}$ causes compressive stress within the scale, which deteriorates the adhesion between scale and substrate by delaminating
Table 2. Calculation of relative integrated density, $I_{(h k l)}$, of $\mathrm{FeO}(\lambda=1.5405 \AA) . \theta$; Bragg angle, $f_{\mathrm{O}}, f_{\mathrm{Fe}}$; atomic scattering factor of $\mathrm{O}$ and $\mathrm{Fe}, p$; multiplicity factor.

\begin{tabular}{|c|c|c|c|c|c|}
\hline index & $\theta$ & $\mathrm{f}_{\mathrm{O}}$ & $\mathrm{f}_{\mathrm{Fe}}$ & $\mathrm{p}$ & $\mathrm{I}_{(\mathrm{hkl})}$ \\
\hline$(111)$ & 18.0 & 5.3 & 18.9 & 8 & $137534(0.599)$ \\
\hline$(200)$ & 21.0 & 4.8 & 17.5 & 6 & $229639(1.000)$ \\
\hline$(220)$ & 30.4 & 3.6 & 14.8 & 12 & $186561(0.812)$ \\
\hline
\end{tabular}

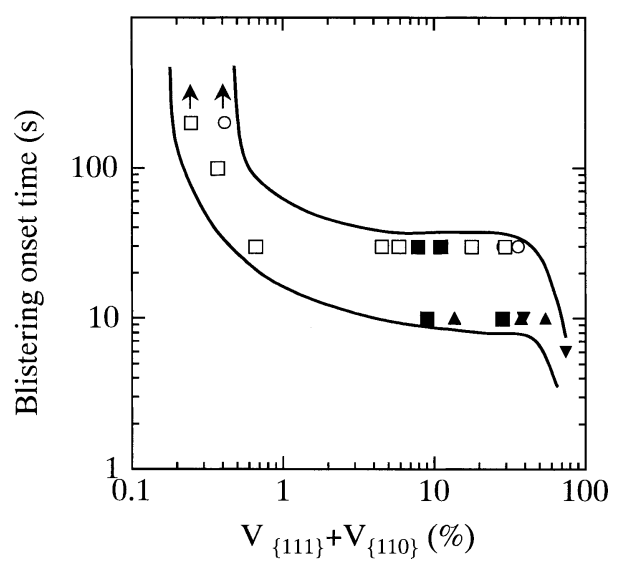

Fig. 10. Relationship between the blistering onset time and the sum of volume fraction of $\{111\}$ and $\{110\}$ oriented crystals in FeO. O; Si steel series-1323 K for $10 \mathrm{~s}$. $\mathbf{\Delta}$; Mn steel series- $1223 \mathrm{~K} \times 6 \mathrm{~s}, \mathbf{\nabla}$; Mn steel series$1173 \mathrm{~K} \times 3 \mathrm{~s}, \square$; P steel series $-1273 \mathrm{~K} \times 10 \mathrm{~s}$, $\mathbf{\square}$; S steel series $-1223 \mathrm{~K} \times 6 \mathrm{~s}$.

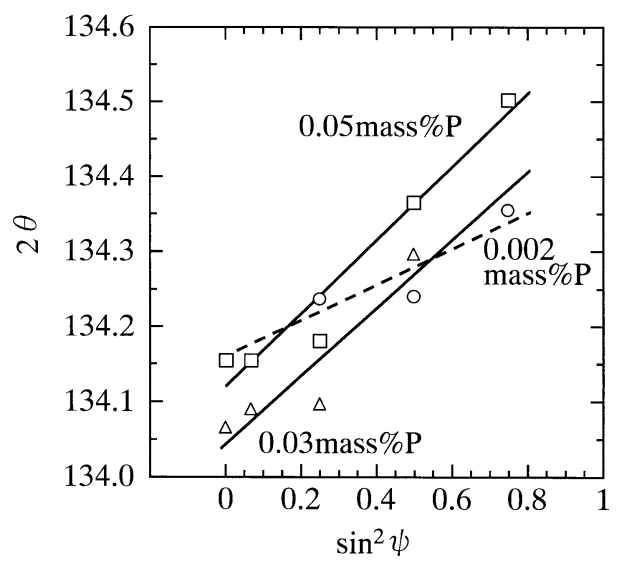

Fig. 11. Relationship between $\sin ^{2} \psi$ and $2 \theta$ in a measurement of residual stress by XRD at $0.05,0.03$ and 0.002 mass $\%$ P steels oxidized at $1273 \mathrm{~K}$ for $10 \mathrm{~s}$.

force. Figure 11 shows the relationship between $\sin ^{2} \psi$ and $2 \theta$ obtained by XRD for $0.002-0.05$ mass $\%$ P steels oxidized at $1273 \mathrm{~K}$, which gives a measure of residual stress. Here, $\psi$ is an angle between the normal direction of the sample face and that of the lattice face, and $2 \theta$ is the diffraction angle. $\psi$ was varied from $0^{\circ}$ to $60^{\circ}$, and $2 \theta$ was varied from $133^{\circ}$ to $136^{\circ}$. As shown in Fig. 11, the gradient is positive, which indicates compressive stress within the scale on cooled specimens. From the gradient in Fig. 11, compressive stress, $\sigma_{1}$, can be calculated as follows, ${ }^{15)}$

$$
\sigma_{1}=E_{\mathrm{FeO}} / 2\left(1+v_{\mathrm{FeO}}\right) \cdot \cot \theta_{0} \cdot \pi / 180 \cdot \partial 2 \theta / \partial \sin ^{2} \psi
$$

here, $E$ is vertical elastic coefficient, $v$ is Poisson's ratio and $\theta_{0}$ is the standard Bragg angle. By using $E_{\mathrm{FeO}}=1.08 \times 10^{3}$ $\mathrm{MPa}$ (measured at $1073 \mathrm{~K}){ }^{21)} \theta_{0}=67.05$ and $v_{\mathrm{FeO}}=0.3, \sigma_{1}$ 


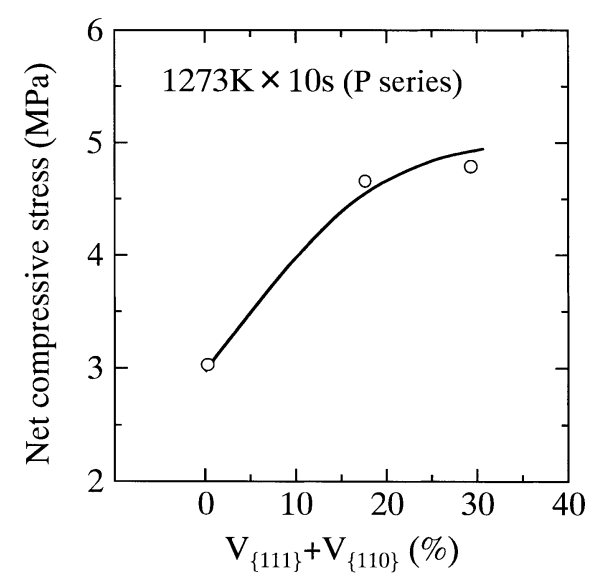

Fig. 12. Effect of the sum of volume fraction of $\{111\}$ and $\{110\}$ oriented crystals in $\mathrm{FeO}$ on the net compressive stress within the scale formed on oxidized P steel series at $1273 \mathrm{~K}$ for $10 \mathrm{~s}$.

can be calculated to increase from 0.71 to $1.47 \mathrm{MPa}$ as the $\mathrm{P}$ content increases.

To evaluate the stress within the scale generated during oxidation, it is necessary to consider the effect of thermal stress caused by a difference in thermal expansion coefficients between the oxide and metal. The thermal stress generated during cooling, $\sigma_{2}$, can be expressed as follows assuming that all the stress operates at the interface between the scale and substrate, ${ }^{22}$ )

$$
\sigma_{2}=\left(E_{\mathrm{Fe}} E_{\mathrm{FeO}} /\left(E_{\mathrm{Fe}}+2 E_{\mathrm{FeO}}\left(t_{\mathrm{FeO}} / t_{\mathrm{Fe}}\right)\right)\right) \Delta T\left(\alpha_{\mathrm{Fe}}-\alpha_{\mathrm{FeO}}\right) \ldots(8
$$

here, $t$ is thickness, $\Delta T$ is difference in temperature, and $\alpha$ is thermal expansion coefficients. Supposing that the effect of temperature on $E$ and $\alpha$ is small, we can use $E_{\mathrm{FeO}}=$ $1.08 \times 10^{3} \mathrm{MPa}$ (measured at $1073 \mathrm{~K}$ ), ${ }^{21)} E_{\mathrm{Fe}}=1.90 \times 10^{5}$ $\mathrm{MPa}(293 \mathrm{~K}),{ }^{23)} \alpha_{\mathrm{FeO}}=13.4 \times 10^{-6} \mathrm{~K}^{-1}(373-1073 \mathrm{~K})^{21)}$ and $\alpha_{\mathrm{Fe}}=14.6 \times 10^{-6} \mathrm{~K}^{-1}(293-1073 \mathrm{~K})^{23)}$ for evaluation of $\sigma_{2}$. With the thermal expansion of steel, it is necessary to consider a change in $\alpha$ due to transformation from ferrite to austenite of steels, $\alpha_{\alpha \rightarrow \gamma}$. Here, the lattice constant of ferrite is $2.8664 \AA$ at $293 \mathrm{~K},{ }^{23)}$ and that of austenite, $a_{\gamma}$, is $3.6468 \AA$ at $1189 \mathrm{~K}^{23)}$ We can calculate the lattice constant of ferrite, $a_{\alpha}$, as $2.9041 \AA$ at $1189 \mathrm{~K}$ by using $\alpha_{\mathrm{Fe}(\text { ferrite) }}$. As ferrite has BCC structure with 2 atoms per unit cell and austenite has FCC structure with 4 atoms per unit cell, $\alpha_{\alpha \rightarrow \gamma}$ can be calculated as follows.

$$
\alpha_{\alpha \rightarrow \gamma}=\left(\left(a_{\gamma}^{3} / 4\right) /\left(a_{\alpha}^{3} / 2\right)\right)^{1 / 3}-1=-3.32 \times 10^{-3}\left(\mathrm{~K}^{-1}\right) . .
$$

Using $t_{\mathrm{FeO}}=20 \mu \mathrm{m}, t_{\mathrm{Fe}}=1500 \mu \mathrm{m}$ and $\Delta T=980 \mathrm{~K}, \sigma_{2}$ can be calculated to be $-2.32 \mathrm{MPa}$, which means tensile stress is generated within the scale during cooling.

Net compressive stress generated within the scale during oxidation at $1273 \mathrm{~K}$ can be estimated by calculating $\sigma_{1}-\sigma_{2}$. Figure 12 shows the relationship between the net compressive stress at $1273 \mathrm{~K}$ and $V_{\{111\}}+V_{\{110\}}$ which increased with increasing $\mathrm{P}$ content as shown in Fig. 9. As $V_{\{111\}}+V_{\{110\}}$ increased, the compressive stress within the scale increased.

In addition to the compressive stress, we discuss the relationship between the scale texture and scale grain size. Figure 13 shows the SEM images of the cross sections of scales formed at $1223 \mathrm{~K}$ on steels with different Mn con-

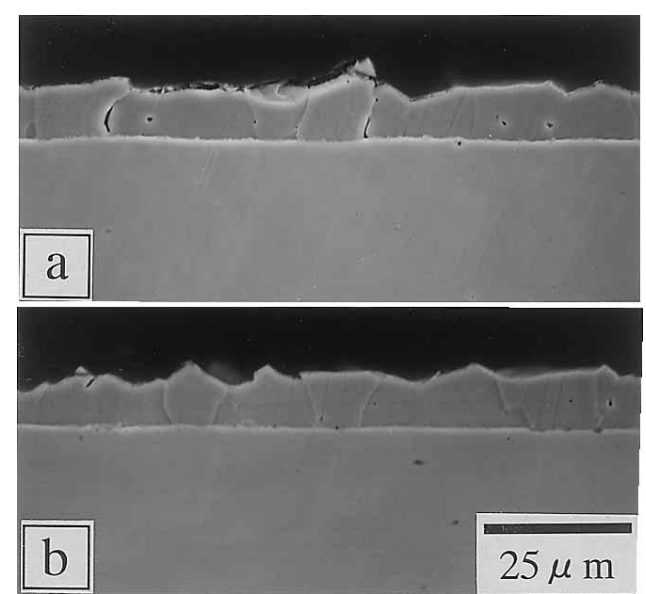

Fig. 13. SEM images of the cross sections of scales formed on oxidized steels at $1223 \mathrm{~K}$ for $6 \mathrm{~s}$. (a) 0.24 mass $\% \mathrm{Mn}$ steel, (b) 1.43 mass $\%$ Mn steel.

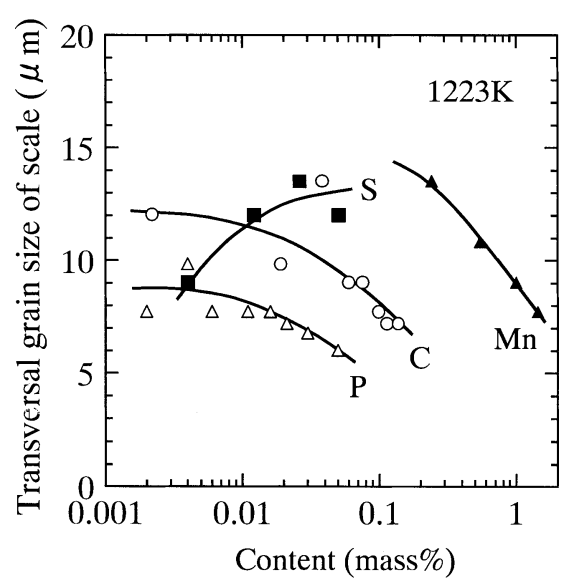

Fig. 14. Effect of chemical composition on transversal grain size of scales formed on oxidized steels at $1223 \mathrm{~K}$ for $10 \mathrm{~s}$ ( $\bigcirc$; C steel series), $6 \mathrm{~s}$ ( $\boldsymbol{\Delta}$; Mn steel series, $\mathbf{\square}$; S steel series) and $3 \mathrm{~s}(\triangle$; P steel series $)$.

tent. For both, grain grew vertically on the steel surface. Figure 14 shows the effect of chemical composition on the transversal grain size of scales formed on oxidized steels at $1223 \mathrm{~K}$ for $3-10 \mathrm{sec}$. The grain size decreased as $\mathrm{C}, \mathrm{Mn}$ and $\mathrm{P}$ contents increased and increased as $\mathrm{S}$ content increased.

The grain size increased as oxidation temperature increased in all samples in this study. It is reported that the nucleation density of scale depends on oxidation temperature, orientation of substrate, grain size, impurity level of substrates, etc. ${ }^{23)}$ and the present results seem to be reasonable ones.

Figure 15 shows the relationship between $V_{\{111\}}+V_{\{110\}}$ and the transversal grain size of scales with variation of impurity levels in the steels. An increase in the grain size corresponded to a decrease in $V_{\{111\}}+V_{\{110\}}$ for all compositions except the carbon steel series. This result supports the idea that the increase in $\{111\}$ and $\{110\}$ oriented crystals in $\{100\}$ matrix of $\mathrm{FeO}$ gives rise to a compressive stress due to different crystal growth rates within textures. With the carbon steel series, it is possible that the high carbon steel needs to select the primary texture, $\{100\}$, strongly due to restraint of oxidation by formation of $\mathrm{CO}$ gas. 


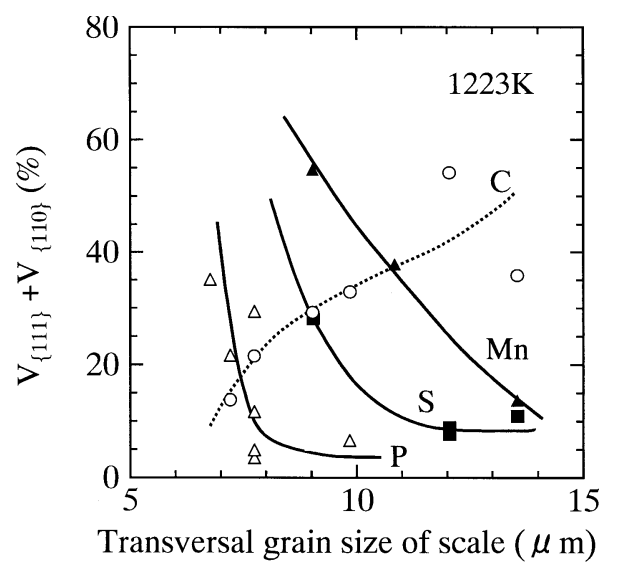

Fig. 15. Relationship between the sum of volume fraction of $\{111\}$ and $\{110\}$ oriented crystals in FeO and transversal grain size of scales formed on oxidized steels at $1223 \mathrm{~K}$ for $10 \mathrm{~s}$ ( $\bigcirc$; C steel series), $6 \mathrm{~s}$ ( $\mathbf{\Delta}$; Mn steel series, $\mathbf{\square}$; $\mathrm{S}$ steel series) and $3 \mathrm{~s}(\triangle$; P steel series $)$.

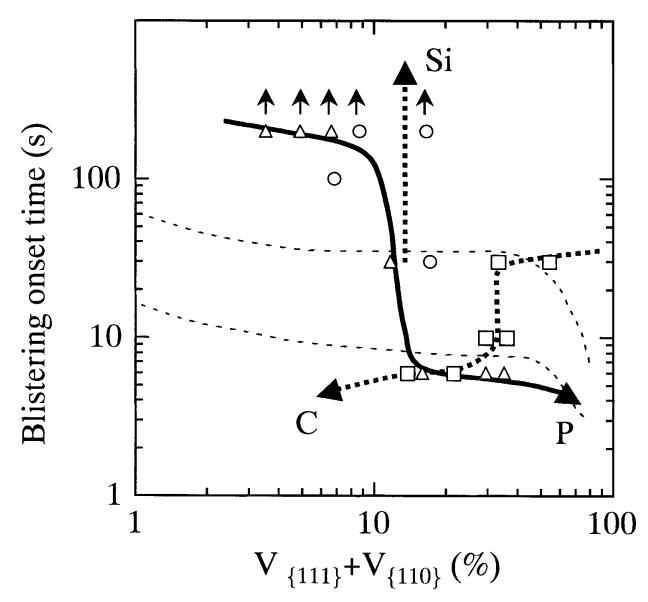

Fig. 16. Relationship between the blistering onset time and the sum of volume fraction of $\{111\}$ and $\{110\}$ oriented crystals in $\mathrm{FeO}$. $\square$; C steel series-1 $223 \mathrm{~K}$ for $10 \mathrm{~s}, \bigcirc$; $\mathrm{Si}$ steel series-1 $223 \mathrm{~K} \times 10 \mathrm{~s}, \triangle$; P steel series-1 $223 \mathrm{~K} \times$ $3 \mathrm{~s}$.

\subsection{Effect of Segregation of Elements on the Adhesion of Scale}

Because Si and P segregated markedly at 1223 K (Fig. 5), effect of segregation on the scale adhesion might be apparent at this temperature. In the case of little segregation, the blistering was influenced by $V_{\{111\}}+V_{\{110\}}$ as shown in Fig. 10. Figure 16 shows the relationship between the blistering onset time and $V_{\{111\}}+V_{\{110\}}$ oxidized at $1223 \mathrm{~K}$ in the specimens those Si content varied 0.01-0.05 mass $\%$, P; $0.002-0.05$ mass $\%$ and C; $0.0022-0.138$ mass $\%$, respectively. Arrow direction shows the increase in content of each element. Hair dotted line shows the tendency in Fig. 10. We cannot explain the blistering only in terms of the $\{111\}$ and $\{110\}$ oriented crystals. That is, Si has little effect on scale texture at $1223 \mathrm{~K}$, but the blistering was suppressed at $\mathrm{Si}$ content above 0.02 mass $\%$. While $\mathrm{P}$ promotes the $\{111\}$ and $\{110\}$ oriented crystals, P below 0.006 mass\% suppressed the blistering and $\mathrm{P}$ above 0.02 mass $\%$ accelerated it more than expected from Fig. 10. Furthermore, in spite of suppression of the $\{111\}$ and $\{110\}$ oriented crystals by an increase in $\mathrm{C}$ content, $\mathrm{C}$ accelerated the blistering.

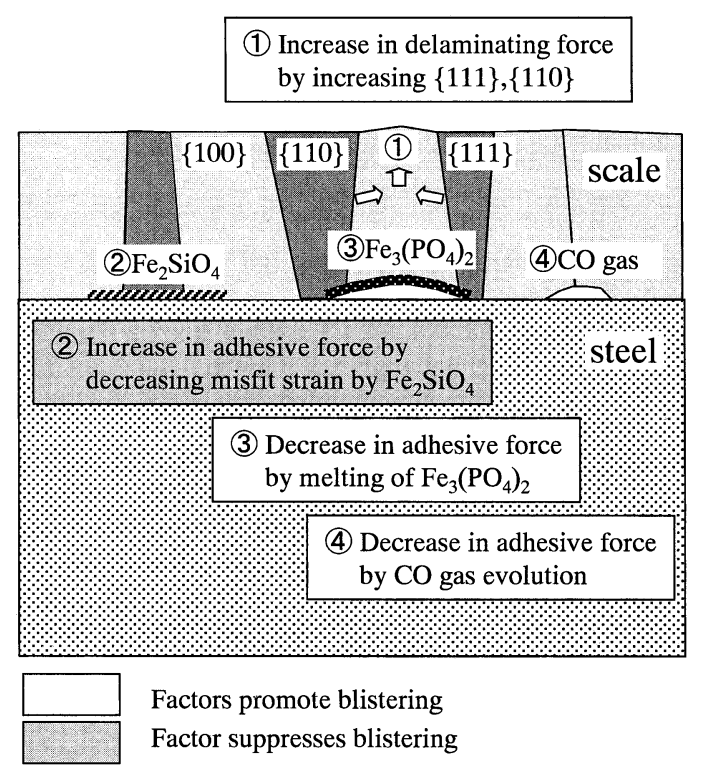

Fig. 17. Factors promoting and suppressing the blistering of scales formed on steels.

Especially, C below 0.002 mass\% suppressed the blistering, and $\mathrm{C}$ above 0.1 mass $\%$ accelerated it more than expected from Fig. 10.

As shown in Fig. 7, Si segregated at the scale side of the interface between scale and substrate and might be equilibrated with $\mathrm{Fe}_{2} \mathrm{SiO}_{4}$ (Fayalite). It is expected that $\mathrm{Fe}_{2} \mathrm{SiO}_{4}$ improves the adhesion of scale as follows. Basically, $\mathrm{FeO}$ forms on the austenite phase of steel by simply placing $\mathrm{O}$ atoms at the oxtahedral sites of the face centered cubic (FCC) cell. Lattice constant of austenite is $3.65 \AA$, and the interatomic distance of $\mathrm{Fe}$ is $2.58 \AA$. The $\mathrm{FeO}$ adopts $\mathrm{NaCl}$ type structure and the lattice constant is $4.31 \AA$, so that the interatomic distance of $\mathrm{Fe}$ is $3.05 \AA$. Therefore, the misfit ratio between the scale and substrate is as large as $18.2 \%$. On the other hand, $\mathrm{Fe}_{2} \mathrm{SiO}_{4}$ has orthorhombic structure of Pbnm space group and the lattice constant of $a_{0}$ is $4.82 \AA^{25}$ ) resulting the interatomic distance of $\mathrm{Fe}$ of $4.82 \AA$. Therefore, the misfit ratio between Fayalite and substrate is as small as $-3.3 \%$. That is, the increase in adhesive force of scale by increasing Si content is explained as a decrease in the misfit ratio between the scale and substrate by the formation of $\mathrm{Fe}_{2} \mathrm{SiO}_{4}$ at the interface.

It has been reported that inclusion of $\mathrm{P}$ in $\mathrm{Fe}-\mathrm{Si}-\mathrm{O}$ system reduces the melting point of oxide to $1163 \mathrm{~K}^{26)}$ by formation of ternary eutectic compound of $\mathrm{FeO}, \mathrm{Fe}_{2} \mathrm{SiO}_{4}$ and $\mathrm{Fe}_{3}\left(\mathrm{PO}_{4}\right)_{2}$. As shown in Fig. 7, Si and $\mathrm{P}$ tend to segregate at the interface and the eutectic compound can form even $\mathrm{Si}$ and $\mathrm{P}$ contents are low in steels. In summary, it is expected that $\mathrm{P}$ segregates and deteriorates the scale adhesion by the formation of liquid phase. For $\mathrm{C}$, it has been reported that the adhesive force is reduced by $\mathrm{CO}$ gas evolution at the interface between scale and substrate. ${ }^{10)}$ The results obtained in this study supports this explanation.

Figure 17 shows the factors that either promote or suppress the blistering. It is concluded that the factors for promotion of the blistering are the increase in the delaminating force by increasing $\{111\}$ and $\{110\}$ oriented crystals and the decrease in the adhesive force by melting of $\mathrm{Fe}_{3}\left(\mathrm{PO}_{4}\right)_{2}$ and $\mathrm{CO}$ gas evolution. Furthermore, it is thought that the 
factor for suppression of the blistering is the increase in the adhesive force caused by the decrease in misfit between scale and substrate by $\mathrm{Fe}_{2} \mathrm{SiO}_{4}$ formation. Especially, $\mathrm{Si}$ and $\mathrm{P}$ segregation is so promoted at $1223 \mathrm{~K}$ that the blistering is strongly affected by them.

\section{Conclusions}

The quantitative effects of the chemical composition and temperature on the scale blistering behavior during oxidation of steels were studied and the following conclusions were obtained.

(1) The temperature at which the time to blistering is the shortest was raised with increasing Si content and reduced with increasing $\mathrm{Mn}$ and $\mathrm{P}$ contents, but $\mathrm{C}, \mathrm{S}$ and sol. Al showed no effect.

(2) The blistering was promoted by increasing $\mathrm{C}, \mathrm{Mn}$ and $\mathrm{P}$ contents, and it was suppressed by increasing $\mathrm{S}$ content. An increase in Si content suppressed the blistering at $1223 \mathrm{~K}$, but promoted it at $1323 \mathrm{~K}$. Sol. Al showed no effect on the blistering.

(3) The mechanism of blistering consisted of four factors as follows, i) an increase in delaminating force by increasing $\{111\}$ and $\{110\}$ oriented crystals in $\{100\}$ matrix of $\mathrm{FeO}$, ii) a decrease in adhesive force by increasing misfit strain by decreasing $\mathrm{Fe}_{2} \mathrm{SiO}_{4}$ formation, iii) a decrease in adhesive force by melting of $\mathrm{Fe}_{3}\left(\mathrm{PO}_{4}\right)_{2}$, iv) a decrease in adhesive force by $\mathrm{CO}$ gas evolution.

(4) C, Mn and P promoted the blistering with the factor iv), i), i)+iii) respectively, and $\mathrm{S}$ suppressed it with the inverse factor of i). Si suppressed the blistering at $1223 \mathrm{~K}$ with the inverse factor of ii), and promoted it at $1323 \mathrm{~K}$ with the factor i).

\section{Acknowledgement}

The authors wish to acknowledge the help and advice received from Mr. M. Yamamoto of National Steel Cor- poration.

\section{REFERENCES}

1) M. Hashimoto, S. Otomo, K. Yoshida, K. Kimura, R. Kurahashi, T. Kawakami and T. Kouga: ISIJ Int., 32 (1992), 1202.

2) K. Goto, Y. Matusda, K. Sakamoto and Y. Sugimoto: ISIJ Int., 32 (1992), 1184.

3) Y. Sano, T. Hattori and M. Haga: ISIJ Int., 32 (1992), 1194.

4) Y. Oike, J. Sato, K. Minami, K. Yoshitake and S. Yamanaka: ISIJ Int., 32 (1992), 1211.

5) K. Goto, T. Koide, T. Sasaki and T. Shibahara: CAMP-ISIJ, 9 (1996), 976.

6) H. Seki, T. Hiruta, M. Yamashita, T. Imae, K. Tominaga and M. Koide: CAMP-ISIJ, 9 (1996), 972.

7) F. Matsuno: Tetsu-to-Hagané, 65 (1979), 599.

8) R. F. Tylecote: J. Iron Steel Inst., 95 (1960), 135.

9) S. Modin: Metal Treatment and Drop Forging, 29 (1962), 89.

10) M. Sugiyama: The Heating and Oxidation of Metals, Seibundo Press, Tokyo, (1965), 61.

11) J. Stringer: Corros. Sci., 10 (1970), 513

12) S. Taniguchi, T. Shibata and M. Murakoshi: Corros. Eng. (Jpn.), 36 (1987), 299.

13) N. B. Pilling and R. E. Bedworth: J. Inst. Met., 29 (1923), 529.

14) N. Birks and G. H. Meier: Introduction to High Temperature Oxidation of Metals, Maruzen, Tokyo, (1988), 33.

15) Handbook of X-ray Diffraction, Rigaku Denki, Tokyo, (1962), 82.

16) G.Petzow: Metallographisches Aetzen, Nikkan Kogyo Shimbun, Tokyo, (1997), 129.

17) S. Hashimoto: Hyomen-Gijutsu, 41 (1990), 817.

18) F. S. Pettit and J. B. Wagner, Jr: Acta Metall., 12 (1964), 35.

19) E. T. Turkdogan, W. M. McKewan and L. Zwell: J. Phys. Chem., 69 (1965), 327.

20) B. D. Cullity: Elements of X-Ray Diffraction, Agne, Tokyo, (1980), 126.

21) Samsonof: Oxide Handbook, Japan Soviet News Agency, Wakayama, (1970).

22) T. Homma: Corros. Eng. (Jpn.), 25 (1976), 251.

23) Metal Data Book, Maruzen, Tokyo, (1993).

24) H. V. Atkinson: Mater. Sci. Technol., 4 (1988), 1052.

25) Steel Handbook, Maruzen, Tokyo, (1981), 436.

26) T. Fukagawa, H. Okada and H. Fujikawa: Tetsu-to-Hagané, 83 (1997), 305. 